\title{
Building programs to address child marriage: The Berhane Hewan experience in Ethiopia
}

Eunice N. Muthengi

Population Council

Annabel Erulkar

Population Council

Follow this and additional works at: https://knowledgecommons.popcouncil.org/departments_sbsr-pgy

Part of the Demography, Population, and Ecology Commons, Family, Life Course, and Society Commons, Gender and Sexuality Commons, Gender Equity in Education Commons, International Public Health Commons, Maternal and Child Health Commons, and the Women's Health Commons How does access to this work benefit you? Let us know!

\section{Recommended Citation}

Muthengi, Eunice N. and Annabel Erulkar. 2010. "Building programs to address child marriage: The Berhane Hewan experience in Ethiopia." Addis Ababa: Population Council. 


\section{Building Programs to Address Child Marriage}

The Berhane Hewan Experience in Ethiopia

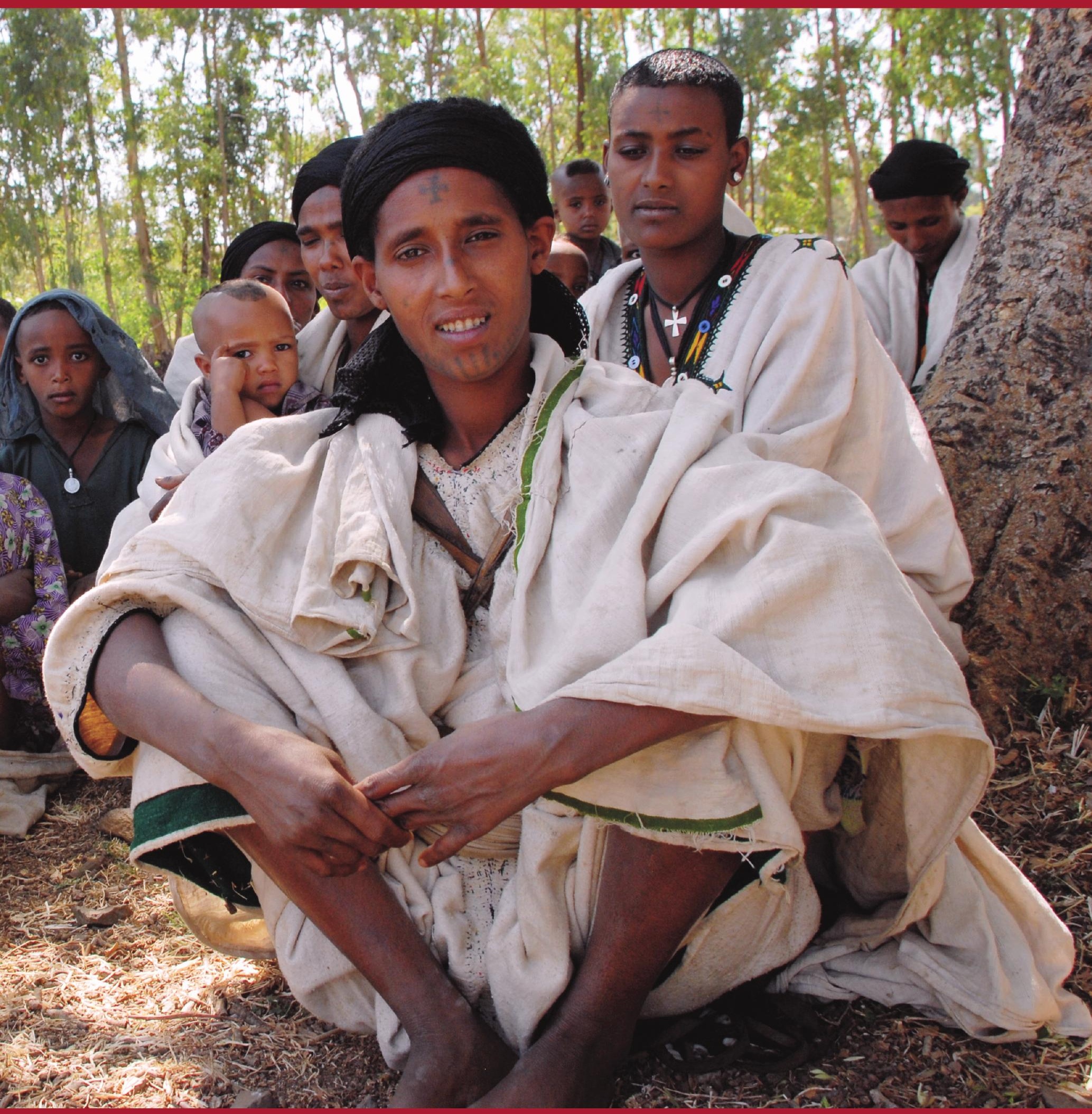



Building Programs to Address Child Marriage The Berhane Hewan Experience in Ethiopia 


\section{(2) Population Council}

The Population Council is an international, nonprofit, nongovernmental organization that seeks to improve the well-being and reproductive health of current and future generations around the world and to help achieve a humane, equitable, and sustainable balance between people and resources. The Council conducts biomedical, social science, and public health research and helps build research capacities in developing countries. Established in 1952, the Council is governed by an international board of trustees. Its New York headquarters supports a global network of regional and country offices.

(C) 2010 The Population Council, Inc.

Population Council

P.O. 25562, Code 1000

Addis Ababa, ETHIOPIA

Tel: (251) (0) 116-631-712/4/6

Fax: (251) (0) 116-631-720

\author{
Population Council \\ One Dag Hammarskjold Plaza \\ New York, NY 10017 USA \\ Tel: (1) 212-339-0500 \\ Fax: (1) 212-755-6052 \\ www.popcouncil.org
}

The United Nations Population Fund is an international development agency that promotes the right of every woman, man and child to enjoy a life of health and equal opportunity. UNFPA supports countries in using population data for policies and programmes to reduce poverty and to ensure that every pregnancy is wanted, every birth is safe, every young person is free of HIV/AIDS, and every girls and women is treated with dignity and respect.

Eunice Muthengi Karei, MPH, PhD is a Senior Program Officer at Population Council's Office in Kenya

Annabel S. Erulkar, Msc, PhD is Country Director of the Population Council's Office in Ethiopia

\section{ACKNowledgements}

This report was made possible through support from UNFPA. We are grateful to the Berhane Hewan project staff who shared their experiences, including collaborators from the Ethiopian Ministry of Women, Children and Youth Affairs, the Amhara Regional Bureau of Women, Children and Youth, and Kebele officials. Many thanks to Ato Tesfahun Wondie and Ato Aragaw Lamesgin who coordinated the qualitative data collection in Amhara. We are grateful to Ato Berhanu Legesse for the excellent comments made on earlier drafts of the report. 


\section{Table of Contents}

I. INTRODUCTION

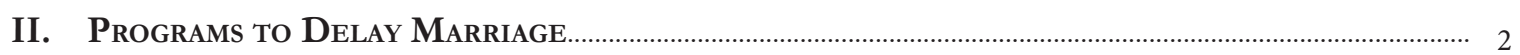

III. The Experience of Adolescent Girls in Amhara Region, Ethiopia...................................... 3

IV. Developing a Program to Delay Marriage .......................................................................................

A. Inventorying youth programs in Ethiopia................................................................................................................... 4

B. Building a picture of early marriage.......................................................................................................................... 5

C. Designing a program based on evidence....................................................................................................................... 6

D. The Berhane Hewan model: Pilot phase

Community conversations ............................................................................................................................ 7

Economic incentives............................................................................................................................... 7

Group formation with mentors................................................................................................................ 8

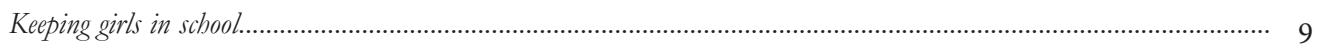

E. Implementing Berhane Hewan as a pilot project............................................................................................. 10

F. Evaluating the Berhane Hewan pilot......................................................................................................................... 11

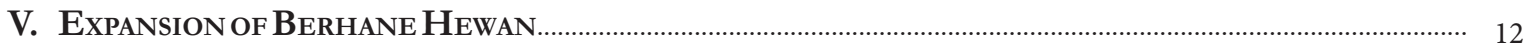

A. The Berhane Hewan model: Expansion phase...................................................................................................

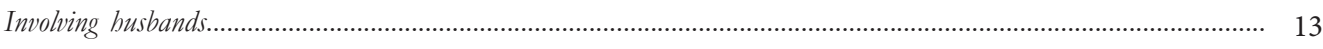

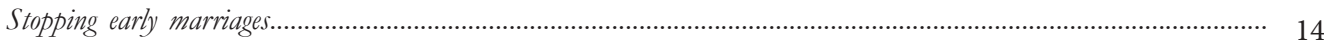

VI. Challenges, Opportunities \& Future Directions .............................................................................

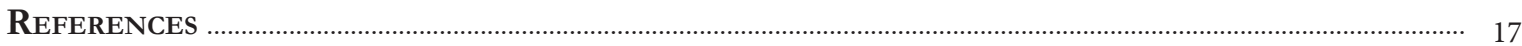




\section{INTRODUCTION}

Early marriage, defined as marriage below the age of 18 , is most prevalent in South Asia and Africa, with 48 percent of women aged 15-24 in South Asia and 42 percent in Africa married by age 18 (UNICEF 2005). Countries with particularly high rates of early marriage include Niger, Chad, Mali, Bangladesh, Guinea, and Burkina Faso. Globally, Ethiopia has the 12th highest rate of early marriage; 49 percent of young women aged 20-24 are married before age 18, and 24 percent are married by age 15 (CSA and ORC Macro 2006; Jain and Kurz 2007).

Early marriage, often driven by poverty and supported by social norms and traditions, is most common in rural areas and in locations where opportunities are limited. In such circumstances, parents are less likely to send girls to school and consider marriage a way to ensure their future. In many settings, the process of marriage entails an exchange of money and assets that frequently benefits the girl's family, as well as having one less mouth to feed when she leaves the household (Mathur, Green and Malhotra 2006). In her husband's household, she becomes an important source of labor in addition to bearing children.

Cultural factors also play a role in perpetuating early marriage. The status of women in some societies is closely tied to their role as wife and mother (Nour 2006). Girls who are not married by late adolescence may be stigmatized. Marrying a girl early gives a family assurance that she will enter marriage as a virgin, averting the shame in cases of premarital pregnancy (Dagne 1994; Mathur, Green and Malhotra 2006; Schuler et al. 2006).

Early marriage is considered a violation of rights, with pronouncements against child marriage found in the Convention on the Elimination of all Forms of Discrimination against Women (CEDAW) (1979), the Convention on the Rights of the Child (CRC) (1989), and the Universal Declaration of Human Rights. According to Ethiopia's Revised Family Code, the legal age of marriage is 18 for both males and females (FDRE, 2000).

Early marriage is associated with numerous adverse effects on girls, including health risks and negative impacts on education and social participation. Girls who marry early generally start their reproductive years earlier than those who marry later, resulting in early childbearing and increased lifetime fertility. The majority of adolescent births in Africa and Asia occur within the context of marriage (Bledsoe and Cohen 1993; WHO 2008). Compared with adult mothers, adolescent mothers are more likely to experience maternal mortality, anemia, and obstetric complications such as fistula. Moreover, their infants are at higher risk for preterm birth, low birth weight, poor nutrition, and fetal death (Adhikari 2003; Makinson 1985; Nour 2006). The health effects of early childbearing operate through a combination of biological, behavioral, and psychological mechanisms (Fraser, Brockert, and Ward 1995; Magill and Wilcox, 2007). Adolescent girls are still growing, so they may not have the adequate weight, nutrition, and pelvis size to carry and deliver a healthy baby. According to the World Health Organization (2009), pregnancy-related complications are the leading cause of death for girls between the ages of 15 and 19 in developing countries. Girls who marry early usually have limited knowledge of or access to family planning. As such, they continue bearing children throughout 
their reproductive years, leading to larger families and continuation of the cycle of poverty.

Studies conducted in Kenya, Zambia, and Zimbabwe show that married adolescent girls are at higher risk of HIV infection compared with unmarried sexually active girls of the same age (Clark 2004; Clark, Bruce, and Dude 2006; Gavin et al. 2006). This is attributed to married adolescent girls usually marrying men who are considerably older and more experienced than themselves, with the profile of their partners placing them at higher risk. In addition, married girls have higher sexual frequency than unmarried sexually active girls and are less likely to use condoms (Clark, 2004, Clark, Bruce, and Dude 2006). The unequal power dynamics between young brides and their older spouses also results in their being more likely to be victims of domestic violence, compared to girls who marry later (Jensen and Thornton 2003; Nour 2006; Otoo-Oyortey and Pobi 2003). Researchers in India found that girls who married before 18 were more likely to have experienced physical and sexual violence in their marriages and were more likely to accept wife beating (Santhya et al. 2010).

Adolescence is a critical period for personal development through schooling and skills acquisition. Early marriage is associated with low levels of education and often ends a girls' chance of furthering her education (Blackburn, Bloom, and Neumark 1993; Klepinger, Lundberg, and Plotnick 1999; Lloyd and Mensch 2008). A study conducted in Bangladesh showed that each additional year marriage was delayed between age 11 and 16 resulted in almost a quarter of a year in additional schooling and a 5.6 percent increase in literacy (Field and Ambrus 2008). In addition to reduced schooling, early marriage also impacts girls' emotional and social development. Marriage reduces girls' social networks and forces girls to take on the roles and responsibilities associated with being wives and mothers before they have fully matured.

\section{Programs to Delay Marriage}

There are limited but increasing numbers of interventions aimed at delaying the age at marriage. Most of the inventions have taken place in South Asia and relatively few have been evaluated. One evaluation in Nepal examined a multicomponent intervention including adolescent-friendly services, peer education and counseling, education and communication, adult and teacher education, youth development, efforts to change social norms, and provisions to improve economic livelihoods (Mathur et al. 2004). Researchers compared data from baseline and endline surveys in control and study sites using qualitative and quantitative methods, and detected an impact on age at marriage in urban areas, but not rural areas.

Studies conducted in Bangladesh have examined indirect effects of education programs and employment opportunities on early marriage. Amin and Sedgh (1998) evaluated the effect of three educational incentive programs in Bangladesh. The Bangladesh Rural Advancement Committee (BRAC) schools gave preferential enrollment to girls, particularly those from poor families and those who had dropped out of school. The Food for Education program, implemented by the government of Bangladesh, provided 15 kilograms of wheat every month to girls from poor families if they enrolled in primary 
school and maintained an 85 percent attendance. The third program was the Female Secondary School Scholarship Scheme, implemented by the government. Scholarships were given to all girls enrolled in $6^{\text {th }}$ to $8^{\text {th }}$ grade provided they maintain a 65 percent school attendance record and a minimum grade average. Participating schools received subsidies, and girls received a monthly stipend of US\$1-\$2. In return, parents were required to sign a contract guaranteeing their daughters would not be married before age 18. The study compared key indicators before the programs were implemented, and after one to two years' implementation. Results showed significant increases in school enrollment, completion, achievement, and progression for girls, as well as a decline in marriage among both boys and girls.

The Kishori Abbijan (Adolescent Girls' Adventure) program was implemented in rural Bangladesh and included life skills and livelihood training, with the aim to increase marriage age. The evaluation matched project participants with similar girls who did not participate. Although there was no significant difference in the timing of marriage between participants and nonparticipants, there was some evidence that the intervention delayed marriage for younger girls in the poorest districts (Amin 2007).

Two programs in the Amhara region of Ethiopia have been shown to improve knowledge and attitudes related to early marriage. The BESO-II CommunityGovernment Partnership Program (CGPP), implemented by World Learning Ethiopia, was a basic education program that included promotion of messages against early marriage. Messages were passed through Girls' Advisory Committees and School Development Agents. Pathfinder International integrated early marriage activities into the community-based project entitled Ethiopian Family Planning and Reproductive Health Project (EFPRHP). Activities addressing early marriage included community conversations (CCs), peer education on harmful traditional practices (HTPs), girls' clubs, and scholarships to encourage poor girls to stay in school. The Early Marriage Evaluation Study (2007) evaluated both programs, by comparing districts where the two programs were implemented with control areas. Findings showed that communities with higher exposure to program messages were more likely to have attitudes favoring delayed marriage, greater knowledge about marriage laws, and a greater number of marriages which had been stopped (Gage 2009).

\section{The Experience of Adolescent Girls in Amhara Region, Ethiopia}

Amhara is the second largest regional state in Ethiopia, with an estimated population of 17.2 million, most residing in rural areas ( 88 percent). Adolescent girls in rural Amhara are characterized by low levels of education, limited social support networks, and high rates of early marriage and early childbearing.

A recent survey in seven regions of Ethiopia suggests that educational participation in Amhara region has increased over time, however educational attainment remains low (Erulkar et al. 2010). Among rural adolescent girls aged 15-19, more than half have never been to school, and only a third had completed more than four years of school. The most common reasons 
given by girls for not attending school were lack of parental approval (53 percent), early marriage ( 24 percent) and poverty (18 percent). Girls also face considerable social isolation, with limited social participation and friendship networks. More than one in four girls $(29$ percent) reported that they have no friends, with married girls and out-of-school girls more likely to report not having friends.

Amhara region has the highest rate of early-adolescent marriage in Ethiopia. Two in five girls ( 39 percent) are married by age 15 . Girls are more likely to marry at an early age than boys, and they tend to marry partners who are much older than themselves. For example, while 18 percent of Amhara boys were married by age 18, 63 percent of girls were married by the same age. Almost all early marriages are arranged by parents ( 94 percent), and most planning related to early marriages take place without the girl's knowledge or consent (Erulkar et al. 2004). The timing of marriage, combined with the low contraceptive use, contributes to high rates of adolescent childbearing in Amhara; one in three girls aged 12-24 has given birth. Limited utilization of maternal health services increases the risk of obstetric complications and maternal mortality. Only a third of adolescent mothers received prenatal care (30 percent), and most of the deliveries occurred at home (88 percent) without assistance from a medical professional.

These findings highlight the educational, health, and social challenges facing adolescent girls in Amhara region. In effect, the average girl in this region is likely to be married before the age of 18 against her will; with little or no education, few friends, and limited knowledge or access to reproductive health services.

\section{Developing a Program to Delay Marriage}

The development of a context-appropriate program to delay marriage in rural Ethiopia took place over many years and in stages. The program that ultimately became known as "Berhane Hewan" was developed by building an evidence base of understanding on the populations being served and developing partnerships between like-minded agencies with complementary expertise.

\section{A. Inventorying youth programs in Ethiopia}

In 2000, the Population Council was exploring the possibility of working with young people in Ethiopia. One of the Council's first activities was to inventory the existing work being done to support youth in the country, especially in the NGO sector. At that time, the inventory of youth programs found the youth populations being served were highly biased toward the relatively advantaged youth and those in urban areas. Many youth programs were being implemented in secondary schools, and delivered life skills education for both boys and girls. However, at the time, enrollment at the secondary level of schooling was less than 20 percent (UNICEF, 2008). This suggested to researchers that those attending secondary school were a selective segment of the youth population. It was largely the most advantaged Ethiopian youth who were able to attain this level of schooling and able to access the existing youth programs. 
Table 1: The Development \& evolution of Berhane Hewan

\begin{tabular}{|c|c|}
\hline Year & Major Activities \\
\hline 2000-1 & $\begin{array}{l}\text { Population Council inventories existing programs for youth in Ethiopia and finds most programs implemented } \\
\text { in urban areas and with relatively 'advantaged' youth }\end{array}$ \\
\hline 2001-2 & $\begin{array}{l}\text { The Ministry of Youth \& Sport and the Population Council undertake qualitative studies in urban slum areas } \\
\text { and rural areas }\end{array}$ \\
\hline 2003 & $\begin{array}{l}\text { Minister of Youth \& Sport requests Population Council to assist with programming for vulnerable adolescent } \\
\text { girls }\end{array}$ \\
\hline \multirow[t]{4}{*}{2004} & Baseline survey conducted in Amhara \\
\hline & Develop interventions for adolescent girls in Amhara \\
\hline & Proposals submitted to UNFPA and Turner Foundation to support pilot project in rural Amhara \\
\hline & Program staff hired for Berhane Hewan pilot project \\
\hline \multirow[t]{5}{*}{2005} & Participant recruitment and community sensitization in Mosebo kebele \\
\hline & Program activities for married and unmarried girls begin \\
\hline & Proposal submitted to UNF, Nike Foundation and UNFPA for program scale up \\
\hline & Community conversation group is formed and dialogue begins \\
\hline & Husbands' groups are formed \\
\hline \multirow[t]{2}{*}{2006} & Six water wells are drilled \\
\hline & Endline survey conducted in Amhara \\
\hline \multirow[t]{5}{*}{2007} & Sheep presented to unmarried participants and their families of pilot project \\
\hline & Berhane Hewan expanded to 12 kebeles in 3 districts \\
\hline & Impact evaluation of Berhane Hewan pilot project published \\
\hline & Additional program staff hired \\
\hline & Participant recruitment and community sensitization in 11 new kebeles \\
\hline \multirow[t]{4}{*}{2008} & Program activities for married and unmarried girls begin in 11 new kebeles \\
\hline & Community conversation groups are formed at all sites and dialogue begins \\
\hline & Husbands' groups are formed in 11 new kebeles \\
\hline & Minister of Youth and Sport approves direct transfer of funds from UNFPA to zones / sub-regions \\
\hline
\end{tabular}

Population Council researchers decided to place emphasis on the most vulnerable and marginalized youth in Ethiopia who would be least likely to be reached by youth programs. The Council made the decision to work in the poorest communities in both urban and rural areas, and focus on youth who were most at risk of negative outcomes.

\section{B. Building a picture of early marriage}

In 2001-2, in partnership with Ethiopia's Ministry of Youth and Sport (MOYS) and with funding from DFID, the Population Council undertook in-depth interviews with different categories of youth in urban slum areas of Addis Ababa and rural areas of Amhara region. Results from the qualitative study assisted researchers to development research instruments for larger surveys in the same areas, undertaken in 2003-4 and supported by UNICEF and UNFPA. In the Merkato area of Addis Ababa, over 1,000 adolescent boys and girls and were interviewed in the survey. In rural areas of Amhara region, over 1,800 adolescents were interviewed (Erulkar et al. 2004). The findings from the Amhara study underscored the high rates of marriage for girls in the region. The study found that the transition to marriage, for girls, was often traumatic and unwanted, and frequently included forced sexual initiation. Married girls were socially isolated and had limited contact with same-age peers or supportive adults. 
I hate early marriage. I was married at an early age and my in-laws forced me to sleep with my husband. He made me suffer all night. After that, whenever it starts to get dark, I get worried thinking that it will be like that. This is what $\mathrm{I}$ hate most. (Ambara girl, age 11, married at age 5, first sex at age 9)

\section{Building a program based on evidence}

As a result, the Amhara Regional Bureau of Youth and Sports (ARBOYS) and the Population Council jointly designed a program to address the high rates of child marriage and support girls who were already married. The Council and MOYS successfully submitted two proposals to UNFPA to support pilot projects in rural and urban areas, with funding also provided by Nike Foundation and the United Nations Foundation.

The Berhane Hewan pilot project began implementation in December 2004 by MOYS, ARBOYS and the Population Council. Berhane Hewan ('Light for Eve' in Amharic) was the name given to the program by community members from Mosebo Kebele Administration (KA), the pilot site of the intervention. The overall goal was to establish appropriate and effective mechanisms to protect and support girls aged 10-19 who were at risk of forced early marriage, and married adolescent girls. Specific objectives were: 1) to reduce the prevalence of early child marriage among adolescent girls; 2 ) to create safe social spaces for the most vulnerable and isolated girls, including access to education; and 3) to increase use of reproductive health services among sexually experienced girls.

\section{The Berhane Hewan model: Pilot phase}

The design of the pilot project addressed the various drivers of early marriage emerging from the research (Table 2). Community conversations addressed the cultural drivers of early marriage, while economic incentives addressed the economic drivers. Addressing girls' social isolation and low social status was achieved through mobilization of girls groups with an adult female mentor. Finally, educational participation was promoted through provision of school supplies, in order to take advantage of the protective effect schooling has against early marriage, as well as its advantages for girls' personal development.

Table 2: Research findings and intervention design

\begin{tabular}{l|l}
\hline \multicolumn{1}{c|}{ Research finding } & \multicolumn{1}{c}{ Intervention component } \\
\hline \multirow{2}{*}{ Communities value early marriage } & $\begin{array}{l}\text { Community conversations to collectively explore community values } \\
\text { and early marriage and engage in collective problem-solving }\end{array}$ \\
\hline \multirow{2}{*}{ There are economic incentives to marry girls early } & $\begin{array}{l}\text { A conditional cash transfer (sheep) is offered to offset the economic } \\
\text { benefit of marrying girls }\end{array}$ \\
\hline \multirow{2}{*}{ Girls are socially isolated and confined to the home } & Girls are mobilized through house to house visits by mentors \\
\cline { 2 - 2 } $\begin{array}{l}\text { Girls at high risk of early marriage have no education } \\
\text { or low levels of education }\end{array}$ & $\begin{array}{l}\text { Girls are formed into girls groups led by adult female mentors } \\
\text { schooling }\end{array}$ \\
\cline { 2 - 2 } & $\begin{array}{l}\text { Provide nonformal education (alternative basic education) for girls } \\
\text { who cannot or do not want to enter the formal school setting }\end{array}$ \\
\hline
\end{tabular}




\section{Community conversations}

Community conversations (CC) is a popular technique in Ethiopia and was used to address the high value the community placed on early marriage. CC is a methodology originally developed by United Nations Development Programme (UNDP) in response to the HIV/AIDS pandemic. The goal of CCs is to transform communities by providing a platform for people to think through the repercussions of a situation, participate in mutual learning, and develop decisions and agreements on how to address challenging issues while preserving dignity and maintaining trust and accountability (UNDP 2004). All mentors and supervisors were trained on the CC model by staff who were highly experienced in CC.

CC groups are formed, each composed of 70 members who registered at the beginning of the project and participated in the ongoing dialogue for the entire implementation period. CC members were strategically selected by program staff to ensure representation by gender and age. They included key stakeholders in the community who had the ability to bring about change and positively influence other community members, such as religious leaders, traditional practitioners/healers, school administrators or teachers, women's association leaders, parents of adolescent girls, and respected elders. Each CC session was led by two mentors; one person facilitated the meeting while the other recorded the minutes and took notes on decisions and action points. CCs were held twice a month, for two-hour periods, during religious holidays or on weekends.

At the beginning of the CCs, facilitators focused on relationship building and problem identification. Each CC formed its own rules and regulations regarding attendance, roles, and responsibilities. Some groups imposed sanctions for tardiness or nonattendance, including fines and chores (such as making tea for the group). Five common problems were identified by each $\mathrm{CC}$ and selected as the primary issues for all to address: early marriage, other harmful traditional practices, HIV/AIDS, gender issues, and family planning. Over time, members discussed each issue, developed an action plan, began implementing the plan, and evaluated progress to identify additional steps that needed to be taken.

Each CC participant was responsible for disseminating key decisions and messages to at least ten households within his/her community. CC members used various resources to communicate program messages, including personal communication with friends or family members, religious events, community events, and government meetings.

\section{Economic incentives}

Researchers identified that economic factors may play a role in the decision to marry girls early. Many parents in rural areas view marriage as a way to ensure their daughters' financial security and status in society, and to improve their own status by forming alliances with other families (Marthur, Green and Malhotra 2006). Early marriage, therefore, allows parents with limited financial resources to recover their investments in their daughters sooner (Nour 2006). Moreover, in situations of dire poverty, marrying a girl off means the family has one less mouth to feed, and may alleviate some of their economic pressures.

To offset the economic benefits associated with marriage, Berhane Hewan included an economic incentive during the pilot phase. During registration, 
parents of unmarried girls were promised a sheep at the end of the two-year period if they agreed not to marry their daughters for the duration of the program. Ultimately, in 2007, sheep were presented to girls and their families in a community ceremony with high level local and federal government leaders and staff from UNFPA and the Population Council. At the end of the pilot project, 650 girls and their families received a sheep.

To obtain the sheep in such large numbers, project staff consulted with agricultural agents to determine the best type of sheep for breeding in that area and they procured the sheep at local markets with assistance from community members. Each of the sheep cost approximately 200 to 250 Ethiopian Birr (approximately $\$ 20$ to $\$ 28 ; 2006$ exchange rate). All were female, and some were pregnant at the time of purchase. This ensured that families could enjoy ongoing economic benefits from breeding the sheep and selling the newborns.

The project provided school materials and a sheep. Even my daughter participated in the project and she got a sheep. Every year, we sell the newborn sheep and use the money to provide clothes and school materials for her. (Father of Unmarried Girl, Mosebo kebele)

\section{Group formation with mentors}

Girls aged 10 to 19 were recruited into the program through house-to-house visits paid by adult mentors. These house-to-house visits allowed mentors to identify if there were eligible girls in the household and ascertain if she was married or unmarried. Married girls were formed into groups of their own, given that local customs often consider married girls to be adults while unmarried girls are still children. The household visit also allowed mentors to familiarize themselves with the girls' family and her home situation. If there was resistance from household members for her participation, the mentor could take additional time to speak with the gatekeeper and assuage any fears or concerns they might have about her participation. Once registered, female mentors were closely involved to oversee the participation and well being of the girls she registered. After club meetings, mentors and supervisors visited the homes of the girls who were absent to find out reasons for absence. They resolved any issues that might prevent girls from attending the meetings, including talking to husbands, if necessary.

Girls participated in biweekly club meetings with other girls in their communities. Separate groups of married and unmarried girls were formed. Girls were split into two groups that met on alternate Sundays. Group meetings provided a safe space where girls could build social networks, participate in social activities, become knowledgeable about matters affecting their wellbeing, and make new friends. During group meetings, mentors used a manual developed by the Population Council to teach girls about reproductive health, early marriage, other harmful traditional practices, HIV/AIDS, and gender norms. Group meetings generally lasted about two hours.

Married girls additionally received livelihood-skills during their club meetings. Mentors collaborated with local government agricultural agents to train the girls in gardening. Using seeds provided by the program, each girl started a small garden in her home compound and received ongoing, personalized support on how to tend the crops. Through this activity, girls were introduced to new gardening techniques and new vegetables, which resulted in improved nutrition for themselves and their families. Participants also received assistance 
in selling the surplus vegetables at the market. Married girls were trained on the importance of saving and guided on how to save the money they earned. Each site formed a revolving savings group and appointed a treasurer and secretary to oversee the funds. Participants contributed a small amount into the account every month, 1 Ethiopian Birr each (US\$.06), from income-generating activities or other sources. Once they had a pool of money, members were allowed to request small loans from the fund.

Home-improvement activities were incorporated into the program during the pilot phase to engage married girls, provide them with tools to reduce their workload, and give them with skills to improve their lives and those of their families. Officials from the Women's Affairs Bureau trained and monitored girls on home-improvement projects. This included the construction of fuelsaving stoves, chairs, beds, and household partitions to separate sleeping areas from cooking and animal quarters. All of these improvements were created using local materials such as wood, hay, and mud. Previously, most women in these communities cooked using an open fire surrounded by three stones; married girls were shown how to make fuel-saving stoves by encircling the open fire with mud and creating two separate cooking areas, thus easing the labor involved in cooking.

To address reproductive health needs, girls were provided with access to family planning services. Program staff sensitized married girls, husbands, and CC participants about the importance of family planning, and that couples should discuss whether or not to use contraceptives. Young women who wanted family planning and other reproductive health services were referred by mentors to the health center in a nearby regional town, Adet. In government facilities, family planning is free and the cost of the clinic card (20 Birr or about US \$2.20) was supported by the project. Later, participants were able to obtain methods from health extension workers.

\section{Keeping girls in school}

Several studies show that girls are less likely to marry or give birth at an early age if they are enrolled in school and if they have at least a primary school education (Gupta and Mahy 2003; Singh 1998; Singh and Samara 1996; Yabiku 2005). School attendance during adolescence can delay the age of marriage in several ways. Education can increase a girl's aspirations by broadening her perspective on the world and presenting her with work opportunities and other alternatives (Jejeebhoy 1995; Yabiku 2005). Educated girls are more likely to have a say in decisions regarding the timing of their marriage and their choice of partner (Mensch, Bruce and Greene 1998). They are also more likely to be aware of the costs and consequences associated with early marriage and more willing to adopt changing social norms favoring the delay of marriage and childbearing (Bates, Maselko and Schuler 2007; Mensch, Bruce and Greene 1998).

Through Berhane Hewan, girls aged 10 to 19 who were currently in school or who wanted to return to school received support to remain there. Those who had never been to school received nonformal education (or alternative basic education). Although the majority of girls in formal and nonformal education groups were unmarried, a small number of married girls who were in school or interested in going back to school also received educational support. When girls registered for the program, the commitment of the parents or guardians was sought by mentors. Both the participating girl and her guardian were 
required to sign the registration form. By signing the form, parents agreed to not marry their daughters, keep them in school, and allow them time to attend program meetings.

Prior to program implementation, mentors were trained in the adult basic education curriculum by the Regional Bureau of Education. Nonformal education participants attended class five days a week, from 8 a.m. to 12 p.m., which included English, Amharic, mathematics and science. Facilities for nonformal education were either renovated or constructed in the project sites. Textbooks were provided by the MOE, and school supplies (pens and exercise books) were provided by Berhane Hewan. Mentors followed the MOE training manual, prepared lessons, and submitted lesson plans on a monthly basis to their supervisors and the district education department for approval. The goal of the 18-month nonformal education program was to provide girls with the basic education necessary to enter the formal education system. The program also helped increase parents' awareness about the importance of education.

After registration, girls who were still in school were supplied with school materials. Every semester, girls were given pens, pencils, and one exercise book for each subject (four subjects in grades one to four, and nine subjects in grades five to nine). Girls were formed into groups and assigned a mentor based on where they lived. Mentors tracked each girl's school attendance and performance by meeting with her teacher to review her grades and absenteeism on a monthly basis. To encourage girls to perform well, the top three in each grade were rewarded with a gift at the end of the semester. Gifts included reference books, book bags, and special notebooks or pens. Mentors visited the homes of girls who were doing poorly in school, girls at risk of dropping out, to discuss their education with their parents. They were generally able to convince parents to allow their daughters to continue going to school; however, if they faced problems, they worked with their supervisors to ensure that the girl went back to school.

Schoolgirls frequently have competing demands on their time that can prevent them from attending school or doing homework. Fetching water is a timeconsuming task which is often assigned to girls. In addition to providing school materials and establishing alternative basic education classes, Berhane Hewan constructed water wells in the project community to bring water sources closer to residents and reduce the amount of time spent in acquiring water.

\section{E. Implementing Berhane Hewan as a pilot project}

In the initial stages of the intervention, a district coordinator (DC) was hired by MOYS to oversee the pilot project in Mosebo kebele. The DC recruited, trained and supervised four female mentors who undertook the field activities. Mentors were leaders in the community and had a minimum of a tenth-grade education. They received an initial five-day training in providing nonformal education, reproductive health, HIV/AIDS, and facilitation techniques. Subsequently, more intensive training on alternative basic education was provided by the Regional Bureau of Education. Recruitment and communitysensitization activities occurred simultaneously in early 2005, and program activities began in March 2005.

Early marriage had been the norm in Mosebo for many generations and was part of the culture, so community sensitization was crucial to the successful implementation of the program. Some community members were 
not interested in changing traditions, whereas others were suspicious of the program and its unfamiliar ideas. In the beginning stages, project staff members and MOYS officials used a variety of strategies to gain the support and trust of the community. A significant investment was made in holding community meetings and individual conversations with influential community members. The support and influence of religious leaders was particularly helpful in gaining community trust. Ultimately, project staff were successful in gaining the community's trust and participation. By the end of the pilot phase, 647 married and unmarried girls had taken part.

\section{F. Evaluating the Berhane Hewan pilot}

Population-based surveys were conducted immediately before the implementation of the Berhane Hewan program and two years afterward, in both pilot and control areas, to measure changes associated with it. Implementation was extremely strong, with the vast majority of girls in the experimental area having heard of the program ( 92 percent) and having been part of groups ( 85 percent). At the same time, no girls in the control area had heard of the program, reflecting no contamination of the control site. An evaluation report released in 2007 described changes associated with the program by comparing baseline and endline characteristics in the experimental (Mosebo Village) and control (Enamirt Village) areas.

The impact evaluation focused on four main areas: social networks and participation, education, marital status, and reproductive health (Erulkar and Muthengi 2007). The program made significant impacts on all the areas of interest, particularly for younger adolescents aged 10-14. After controlling for marital status, age, and socioeconomic status, Mosebo girls aged 10-14 were nearly three times more likely to be in school, compared with girls in the control area. Multivariate analysis revealed the considerable impacts on the timing of marriage for younger adolescents aged 10-14. Mosebo girls aged 10-14 were 90 percent less likely to be married compared to Enamirt girls. Not one girl aged 10-14 in Mosebo had been married during the previous year. On the other hand, marriage seemed to accelerate for older girls in Mosebo after the age of 15 , perhaps due to the social expectation for marriage during adolescence and its linkage with the status of the girl's father.

Family planning use increased in both areas, but more so in the experimental site. There were no significant differences in the use of family planning methods at baseline. At endline, however, Mosebo girls were nearly three times more likely to have used any family planning method compared to controls, after adjusting for demographic factors.

The Berhane Hewan pilot demonstrated that significant impacts can be made on the social, educational, and health status of adolescent girls in a short period of time, through well designed and implemented support programs. However, high levels of exposure to all project components, however, make it difficult to ascertain if specific program components were more influential in bringing about change than others. 


\section{Expansion of Berhane Hewan}

During the pilot phase, the Population Council and MOYS developed a proposal for the scale up of Berhane Hewan. The United Nations Foundation (UNF), Nike Foundation and UNFPA funded the proposal for the joint UNFPA, MOYS, and Population Council project.

In July 2007, the Berhane Hewan program was expanded to a total of 12 kebeles in West Gojjam Zone, including three additional kebeles in Yilmana Densa district, and four in both Mecha and South Achefer districts (see Appendix, Table 1A). Program staff were recruited in November 2007. In each district, a District Coordinator (DC) was hired by MOYS to supervise female supervisors and mentors and to oversee all financial and program activities. Twelve supervisors and 32 additional mentors were hired during the scale up. Each district had 4 supervisors and 12 mentors, with 1 supervisor overseeing 3 mentors (Figure 1). At the end of 2007, program staff mobilized community members in each village, sensitized the community about the project, and recruited married and unmarried girls to participate in program activities, which were launched in January 2008.

\section{Figure 1: Organizational Structure of Berhane Hewan Expansion}

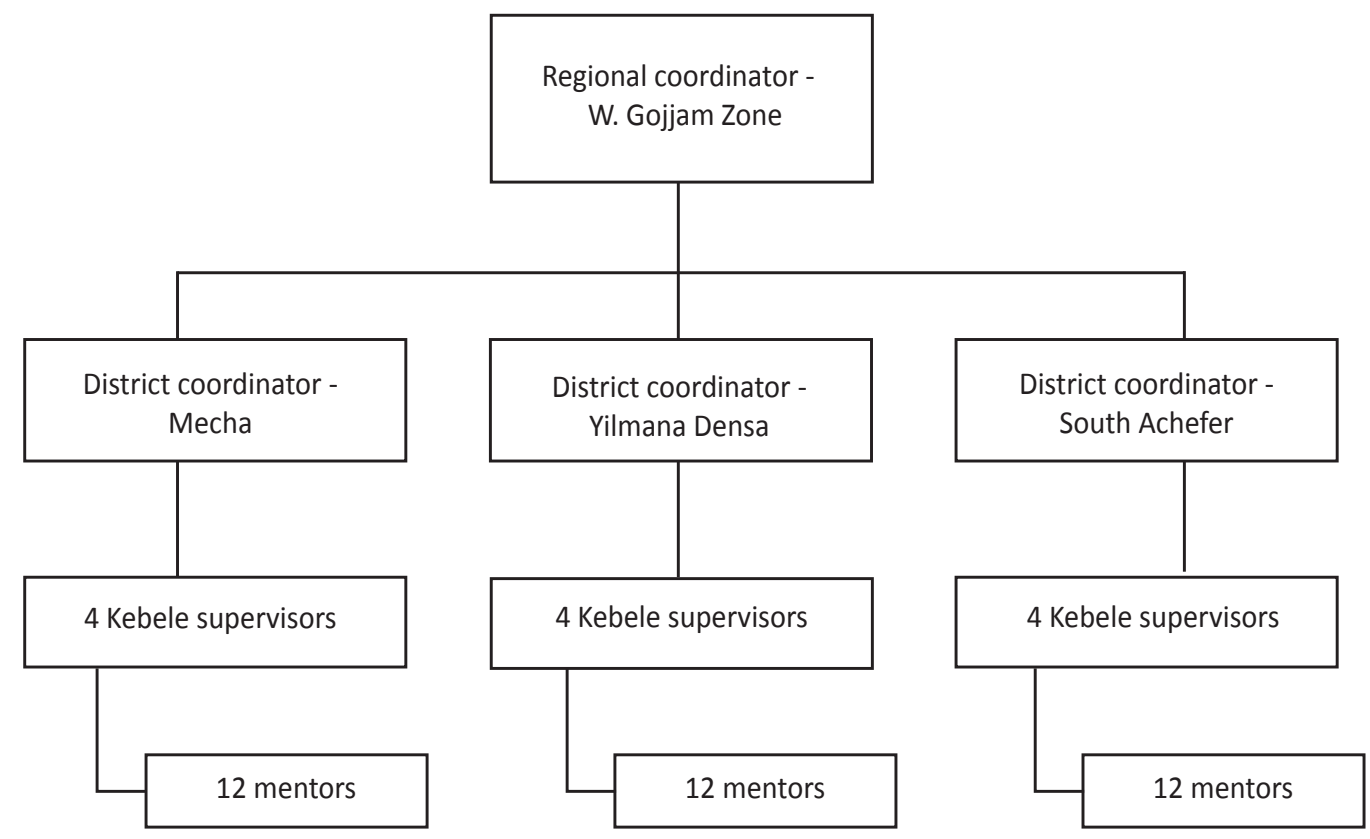


Table 3 Number of Girls (aged 10-19) Participating in Berhane Hewan at Registration

\begin{tabular}{lcccc}
\hline & Formal education & Nonformal education & Married girls group participants & TOTAL \\
\hline Pilot project & 437 & 84 & 126 & $\mathbf{6 4 7}$ \\
\hline Scaled-up program & & & & $\mathbf{2}, 919$ \\
Mecha & 2,249 & 199 & 471 & $\mathbf{2 , 7 5 0}$ \\
Yilmana Densa & 2,259 & 107 & 384 & $\mathbf{4 , 1 5 0}$ \\
South Achefer & 2,495 & 229 & 1,426 & $\mathbf{1 0 , 4 6 6 ( 1 0 0 \% )}$ \\
\hline TOTAL & $\mathbf{7 , 4 4 0}(\mathbf{7 1 \% )}$ & $\mathbf{6 1 9 ( 6 \% )}$ & $\mathbf{2 , 4 0 7}(\mathbf{2 3 \% )}$ & \\
\hline
\end{tabular}

A total of 10,466 girls participated in Berhane Hewan (Table 3): 647 during the pilot phase and 9,819 during the scale-up phase. More than two-thirds of participants (71 percent) received support to stay in school, 6 percent received nonformal education, and 23 percent participated in married girls' groups.

\section{A. The Berhane Hewan Model: Expansion Phase}

The pilot phase of Berhane Hewan included community conversations, group mobilization and girls' meetings led by mentors, support to remain in school, and an economic incentive to keep girls unmarried and in school. This combination of interventions proved successful in a small-scale pilot in one kebele, Mosebo. However, there were concerns that upscaling the full model of four components would be unsustainable. In particular, concerns were expressed that provision of the economic incentive (sheep) would be unachievable on a large scale. Based on the success of the pilot, the next step in program learning should have been to ascertain which specific components of the program were the most influential in delaying marriage and promoting schooling, the outcomes achieved during the pilot phase. Indeed, some additional analysis of the survey data conducted by the Population Council suggested that provision of school material could be the most influential factor in keeping girls unmarried (Population Council, 2009).

Rather than attempting to identify a core basic package to delay marriage that could be further upscaled and sustained, program managers added new components to the program. The expansion phase of Berhane Hewan eliminated the individual-level economic incentive, retained the provision of water wells which managers considered a community incentive, and added a component to include husbands and activities to enforce the prevention of child marriage.

\section{Involving husbands}

Project managers observed that married girls' clubs were characterized by high rates of drop-out and low attendance. Some husbands remained suspicious about the groups and did not support their wives' attendance. As a result, administrators decided to form husbands' clubs. All husbands of participating married girls were invited to attend weekly meetings of husbands, following a similar format as the married girls' clubs. By discussing the same topic with husbands and wives each week, mentors helped couples to develop a mutual understanding about gender and reproductive health, which facilitated marital communication and joint decision making. Program staff members observed a marked improvement in the attendance of married girls after these clubs were formed. Husbands became more supportive of wives' participation and more receptive to wives' interest in family planning and voluntary counseling and testing (VCT) for HIV. 


\section{Stopping Early Marriages}

Although all program components were aimed at preventing early marriage, staff also intervened directly to stop marriages from taking place during the expansion phase. Given the community attention to the issue, some parents began to hide early marriage by conducting it in secret or at night. As a result, program staff developed anonymous suggestion boxes at each kebele center where community members could report potential early marriages, including girls' own marriages, without disclosing their identity. Mentors and supervisors followed up on these cases by visiting girls' homes and attempting to convince parents to stop the marriage. In cases where parents were unwilling to change their minds, mentors recruited influential CC members to intervene. When all discussions failed, project staff involved the local police, kebele administrators, and Women's Affairs officials, or, ultimately district administrators. Such approaches, however, ultimately endanger those involved as one does not know the repercussions within the family or to the girl herself, once outsiders have intervened in family matter. In addition, other projects using this approach have witnessed retaliation and violence exacted on those attempting intervention.

\section{Vi. Challenges, Opportunities \& Future Direction}

Berhane Hewan has faced challenges in implementation. Project staff complain of budget delays and bureaucratic procedures that hinder effective implementation. In late 2008, this issue was raised during a biannual program meeting, and the Minister of Youth and Sport made an unprecedented decision to effect the direct transfer of program funds from the donor to the zonal government, a decision that greatly improved the smooth running of the project. However, budget delays persisted, partly because of the bureaucratic financial system.

To an extent, collaborators missed opportunities to extend program learning during the expansion phase. The pilot phase identified that the package of four components were highly effective in delaying the earliest marriage and increasing educational participation. Given concerns about cost and sustainability, the next logical step should have been to understand, through research, which subset of the original four activities were most influential in achieving the positive outcomes. Instead, managers made the decision to eliminate individual incentives, based on concerns expressed by government and donors, without further examination of its impact on age at marriage or education. At the same time, additional components were added, potentially undermining prospects for sustaining activities.

The collaboration with MOYS and ARBOYS was a strong point for the success of Berhane Hewan. ARBOYS provided many of the resources that facilitated the day-to-day activities, such as office space and infrastructure. ARBOYS also facilitated collaboration with other government agencies such as the Regional Bureau of Education for training and in the provision of textbooks for nonformal education; the Ministry of Agriculture in training and monitoring of gardening activities; and the Ministry of Women's Affairs in training and monitoring of livelihoods activities. Government implementation has meant that scale could be rapid, covering vast areas in relatively short periods. 
Implementation by a government agency (now, Ministry of Women, Children and Youth Affairs) continues to be Berhane Hewan's greatest strength. In addition, program and technical support that is evidence-based and keeps the girl at the center of programming decisions and investments has been critical to success.

Berhane Hewan was one of the first programs in Africa to have the explicit objective to delay marriage age for girls. It remains as a groundbreaking and influential program addressing child marriage in Africa, and has paved the way for a second generation of program development on the topic. Indeed, when 'The Elders' (Archbishop Desmund Tutu, Dr. Gro Brundtland, and Mrs. Mary Robinson) chose to visit programs devoted to child marriage in order to inaugurate their focus on the topic, one project they visited was Berhane Hewan. Berhane Hewan will continue implementation in the Awi zone of Amhara region, by the Amhara Regional Bureau of Women, Children and Youth and the Population Council, with support from USAID. In this phase, researchers will test the relative effects of Berhane Hewan components on marriage age and educational participation. With support from DFID, the End Child Marriage Programme will be implemented in East and West Gojjam of Amhara region, building on lessons from the Berhane Hewan experience. 


\section{Appendix}

Table 1A: Berhane Hewan expansion sites

\begin{tabular}{ll}
\hline District & Kebeles \\
\hline Mecha & Enamirt \\
& Enashenfalen \\
& Bachima \\
& Andinet \\
South Achefar & Lalibella \\
& Guta Adbi \\
& Caregurach \\
& Ahurikeltafa \\
& Mosebo \\
Yilimana Densa & Debre Mewi \\
& Tsion \\
& Sentenga \\
\hline
\end{tabular}




\section{REFERENCES}

Adhikari, R.K. 2003. "Early Marriage and Childbearing: Risks and Consequences." Pp. 62-66 in Towards Adulthood: Exploring the Sexual and Reproductive Health of Adolescents in South Asia, edited by Sarah Bott, Shireen Jejeebhoy, Iqbal Shah, and Chander Puri. Geneva: World Health Organization.

Amin, Sajeda. 2007. "Empowering Adolescent Girls in Rural Bangladesh: Kishori Abhijan.” In Promoting Healthy, Safe and Productive Transitions to Adulthood. New York, NY: Population Council.

Amin, S., and G. Sedgh. 1998. "Incentive Schemes for School Attendance in Rural Bangladesh.” in Working Paper 106. New York: Population Council.Bates, L. M., J. Maselko, and S. R. Schuler. 2007. "Women's Education and the Timing of Marriage and Childbearing in the Next Generation: Evidence from Rural Bangladesh.” Stud Fam Plann 38(2):101-12.

Bates, L. M., Maselko, J., and Schuler, S. R. 2007. "Women's Education and the Timing of Marriage and Childbearing in the Next Generation: Evidence from Rural Bangladesh.” Stud Fam Plann 38:101-12.

Blackburn, M. L., D. E. Bloom, and D. Neumark. 1993. “Fertility Timing, Wages, and Human-Capital.” Journal of Population Economics 6(1):1-30.

Bledsoe, C, and B Cohen. 1993. Social Dynamics of Adolescent Fertility in Sub-Saharan Africa. Washington, D.C.: National Academy Press.

Clark, S. 2004. "Early Marriage and HIV Risks in Sub-Saharan Africa.” Stud Fam Plann 35(3):149-60.

Clark, S., J. Bruce, and A. Dude. 2006. "Protecting Young Women from HIV/AIDS: The Case against Child and Adolescent Marriage." Int Fam Plan Perspect 32(2):79-88.

CSA, and ORC Macro. 2006. "Ethiopia Demographic and Health Survey 2005.” Addis Ababa, Ethiopia, and Calverton, MD, USA: Central Statistical Agency and ORC Macro.

Dagne, Haile Gabriel. 1994. “Early Marriage in Northern Ethiopia.” Reproductive Health Matters 2(4):35-38.

Erulkar, Annabel, Abebaw Ferede, Worku Ambelu, Woldemariam Girima, Helen Amdemikael, Behailu GebreMedhin, Berhanu Legesse, Ayehualem Tameru, and Messay Teferi. 2010. "Ethiopia Youth Adult Survey: A Study in Seven Regions." Addis Ababa, Ethiopia: Population Council.

Erulkar, Annabel, T. Mekbib, N. Simie, and T. Gulema. 2004. “The Experience of Adolescence in Rural Amhara Region Ethiopia." Accra: Population Council.

Erulkar, Annabel, and Eunice Muthengi. 2007. "Evaluation of Berhane Hewan - a Pilot Program to Promote Education and Delay Marriage in Rural Ethiopia." New York: Population Council.

Federal Democratic Republic of Ethiopia (FDRE). 2000. “The Revised Family Code Proclamation No. 213/2000.” Federal negarit Gazetta.

Field, Erica, and Attila Ambrus. 2008. "Early Marriage, Age of Menarche, and Female Schooling Attainment in Bangladesh.” Journal of Political Economy 116(5):881-930.

Fraser, Alison M., John E. Brockert, and R. H. Ward. 1995. "Association of Young Maternal Age with Adverse Reproductive Outcomes." N Engl J Med 332(17):1113-18.

Gage, Anastasia. 2009. "Coverage and Effects of Child Marriage Prevention Activities in Amhara Region, Ethiopia —Findings from a 2007 Study.” Chapel Hill: MEASURE Evaluation.

Gavin, L., C. Galavotti, H. Dube, A. D. McNaghten, M. Murwirwa, R. Khan, and M. St Louis. 2006. "Factors Associated with HIV Infection in Adolescent Females in Zimbabwe." J Adolesc Health 39(4):596 e11-8.

Gupta, N., and M. Mahy. 2003. "Adolescent Childbearing in Sub-Saharan Africa: Can Increased Schooling Alone Raise Ages at First Birth?” Demographic Research 8(4):93-106.

Jain, Saranga, and Kathleen Kurz. 2007. “New Insights on Preventing Child Marriage.” Washington, DC: International Center for Research on Women (ICRW). 
Jejeebhoy, Shireen J. 1995. "Education and Women's Age at Marriage." Pp. 60-77 in Women's Education, Autonomy, and Reproductive Behaviour: Experience from Developing Countries, edited by Shireen J. Jejeebhoy. Oxford, England: Clarendon Press.

Jensen, Robert, and Rebecca Thornton. 2003. "Early Female Marriage in the Developing World.” Gender \& Development 11(2):9-19.

Klepinger, D., S. Lundberg, and R. Plotnick. 1999. "How Does Adolescent Fertility Affect the Human Capital and Wages of Young Women?” Journal of Human Resources 34(3):421-48.

Lloyd, C. B., and B. S. Mensch. 2008. "Marriage and Childbirth as Factors in Dropping out from School: An Analysis of Dhs Data from Sub-Saharan Africa.” Popul Stud (Camb) 62(1):1-13.

Magill, M. K., and R. Wilcox. 2007. “Adolescent Pregnancy and Associated Risks: Not Just a Result of Maternal Age.” Am Fam Physician 75(9):1310-1.

Makinson, C. 1985. “The Health Consequences of Teenage Fertility.” Fam Plann Perspect 17(3):132-9.

Mathur, S., M. Green, and A. Malhotra. 2006. "Too Young to Wed: The Lives, Rights and Health of Young Married Girls." Washington, DC: ICRW.

Mathur, S., M. Mehta, A. Malhotra, and J. R. Ickovics. 2004. "Youth Reproductive Health in Nepal: Is Participation the Answer?" Washington, DC: International Center for Research on Women; EngenderHealth.

Mensch, B. S., J. Bruce, and M. Greene. 1998. “The Uncharted Passage: Girls’ Adolescence in the Developing World.” New York: Population Council.

Nour, N. M. 2006. "Health Consequences of Child Marriage in Africa.” Emerg Infect Dis 12(11):1644-9.

Otoo-Oyortey, Naana, and Sonita Pobi. 2003. "Early Marriage and Poverty: Exploring Links and Key Policy Issues.” Gender \& Development 11(2):42 - 51.

Population Council. 2009. Unpublished data analysis on Berhane Hewan evaluative surveys, May.

Santhya, K. G., U. Ram, R. Acharya, S. J. Jejeebhoy, F. Ram, and A. Singh. 2010. "Associations between Early Marriage and Young Women's Marital and Reproductive Health Outcomes: Evidence from India." International Perspectives on Sexual and Reproductive Health 36(3):132-9.

Schuler, S. R., L. M. Bates, F. Islam, and M. K. Islam. 2006. "The Timing of Marriage and Childbearing among Rural Families in Bangladesh: Choosing between Competing Risks.” Soc Sci Med 62(11):2826-37.

Singh, S. 1998. “Adolescent Childbearing in Developing Countries: A Global Review." Stud Fam Plann 29(2):117-36.

Singh, Susheela, and Renee Samara. 1996. "Early Marriage among Women in Developing Countries.” International Family Planning Perspectives 22(4):148-75.

UNDP. 2004. "Upscaling Community Conversations in Ethiopia: Unleashing Capacities of Communities for the HIV/AIDS Response.” Addis Ababa, Ethiopia.

UNICEF. 2005. “Early Marriage. A Harmful Traditional Practice: A Statistical Exploration.” New York, NY: UNICEF.

UNICEF. 2008. Division of Policy and Practice, Statistics and Monitoring Section, www.childinfo.org, May.

WHO. 2008. “Why Is Giving Special Attention to Adolescents Important for Achieving Millennium Development Goal 5?” in Fact Sheet WHO/MPS/09.14. Geneva, Switzerland: World Health Organization.

WHO. 2009. “Women's Health .” in Fact Sheet WHO/N 334. Geneva, Switzerland: World Health Organization.

Yabiku, S.T. 2005. “The Effect of Non-Family Experiences on Age of Marriage in a Setting of Rapid Social Change.” Population Studies 59(3):339-54. 



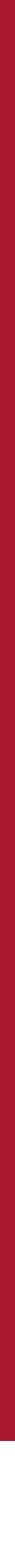

